\title{
BIOLOGICAL MONITORING OF POLYCYCLIC AROMATIC HYDROCARBONS AS A POSSIBLE RISK FACTOR OF HEPATOCELLULAR CARCINOMA AMONG CASES OF CHRONIC ACTIVE HEPATITIS B AND C
}

\author{
By \\ Raed M Alazab*, Alaa Abdelwahed*, Elham A. Motawea**, Sherief A. \\ Morsy***, and Ahmed E. AbdRaboh* \\ * Department of Community medicine and Occupational medicine, Faculty of Medicine, \\ Al-Azhar University, Cairo, Egypt \\ ** Department of Clinical Pathology, Faculty of Medicine, Al-Azhar University, Cairo, \\ Egypt \\ *** Hepatology and Gastroentrology Theodor Bilharz Research institute, Cairo, Egypt
}

\begin{abstract}
Background: Polycyclic aromatic hydrocarbons (PAHs) are among the most carcinogenic, mutagenic and toxic contaminates. Their exposure and metabolism to DNA-reactive metabolites in the body are considered to contribute to the etiology of many types of the human cancers.

Objectives: To find out if exposure to polycyclic aromatic hydrocarbons is a risk factor for development of hepatocellular carcinoma (HCC) among the exposed cases, to detect if the smoking is an augmented factor for development of hepatocellular carcinoma among exposed cases, and to find the effect of sociodemographic characteristics of cases of hepatocellular carcinoma exposed to hydrocarbons.

Subjects and Methods: A case control study was conducted between the period from the first of March 2015 to end of August 2017. The study was conducted in the outpatient clinic of the Department of Hepatology and Gastro-entrology at Theodor Bilharz Research Institute (TBRI). The minimum sample size required for the present study was calculated using Epi info program, considering following data: Two sided confidence level $=95 \%$, power of test $=80 \%$, ratio of control: cases $=1: 1$, percent of control exposed $=21 \%$, percent of cases exposed $=42 \%$, and odds ratio $=2.8$. Kelsey estimated number of cases $=77$ and number of control $=77$ subjects. All subjects of both groups were interviewed. Every patient was subjected to the selected interview sheet and biological monitoring of urinary 1-hydroxy pyrene as a biomarker for PAHs exposure.
\end{abstract}

Results: $73 \%$ of cases of HCC had increased level of 1-hydroxy pyrene in urine with statistical significance difference when compared to controls. There was a significant positive association between exposure to PAHs and development of HCC among case group $(\mathrm{OR}=4.9)$. There was a significant association between smoking and abnormal high level of 1-hydroxy pyrene in urine $(\mathrm{OR}=1.7)$ among the case group. There was a significant positive association between exposure to PAHs and development of HCC among males (OR = 1.6). There was neither statistical significance difference nor positive association between exposure to PAHs and development of $\mathrm{HCC}$ in urban areas $(\mathrm{OR}=0.8)$. There was a statistically significant positive association between exposure to PAHs and development of HCC among smoker $(\mathrm{OR}=1.7)$. There was neither statistical significance nor positive association between exposure to PAHs and development of HCC among patients with chronic active hepatitis $\mathrm{C}(\mathrm{OR}=0.6)$. There was a highly positive correlation between 1-hydroxy pyrene and Alfa Feto Protein (AFP) among positive cases of 1-hydroxy pyrene in case group ( $\mathrm{OR}=316.25)$. 
Conclusion: Exposure to PAHs is considered as a risk factor of HCC among cases of hepatitis B and C. HCC cases had increased level of 1-hydroxy pyrene in urine with statistical significance difference when compared to controls. A significant positive association between exposure to PAHs and development of HCC among males and smokers were also detected.

Keywords: 1-hydroxy pyrene, HCC. Hepatitis B, Hepatitis C, PAHs.

\section{INTRODUCTION}

Polycyclic aromatic hydrocarbons (PAH) are major pollutants in the environment formed during incomplete combustion of organic materials such as gasoline, diesel fuel, coal and oil. The substances are therefore found in heavily polluted air, water, soil and smoked food (WHO, 2013).

Polycyclic aromatic hydrocarbons (PAHs) are among the most carcinogenic, mutagenic and toxic contaminates. Their exposure and metabolism to DNAreactive metabolites in the body are considered to contribute to the etiology of many types of the human cancers (EEAA, 2011).

Uptake of PAH in the body may be monitored by different biomarkers, for example metabolites in urine, urinary thioethers, urinary mutagenicity, PAHprotein adducts, and PAH-DNA adducts (Angerer and Schaller, 2009).

Hepatocellular carcinoma (HCC) is a major cause of cancer death worldwide, Its incidence is increasing, ranging between $3 \%$ and $9 \%$ annually depending on the geographical location, and variability in the incidence rates correspond closely to the prevalence and pattern of the primary etiologic factors (El-Zayadi et al., 2011).

Ezzat et al. (2014) stated that during the last 5-10 years, high incidence of HCC in Egypt which reaches about $21 \%$ in cirrhotic patients.
In a single center study over a decade in Egypt reported that, chronic infections with HBV or HCV have both been recognized as human liver carcinogens with a combined attributable fraction of at least $75 \%$ of all HCC cases (Hassan et al., 2011).

It was observed that the incidence of HCC all over the world is increasing year by year with no definite exploration for this problem. However, PAHs might be a risk factor especially among the cases of chronic active hepatitis $\mathrm{B}$ and $\mathrm{C}$.

The present work aimed to find out if exposure to polycyclic aromatic hydrocarbons is a risk factor for development of hepatocellular carcinoma among the exposed cases, to detect if the smoking is an augmented factor for development of hepatocellular carcinoma among exposed cases, and to find the sociodemographic characteristics of cases of hepatocellular carcinoma.

\section{SUBJECTS AND METHODS}

This was a case control study which was conducted between the period from the first of March 2015 to end of August 2017. The study was conducted in the outpatient clinic of the Department of Hepatology and Gastro-entrology at Theodor Bilharz Research Institute (TBRI). The minimum sample size required for the present study was calculated using Epi info program, considering the following data: Two sided confidence level $=95 \%$, power of test $=$ 
$80 \%$, ratio of control to cases $=1: 1$, percent of control exposed $=21 \%$ (El-Zayadi et al., 2011), percent of cases exposed $=42 \%$, and odds ratio $=$ 2.8. Kelsey estimated number of cases $=$ 77 , and number of control $=77$ subjects. The sample was selected from all cases registered at the place of the study and regularly followed up at the outpatient clinic. Cases were defined as patients with chronic active hepatitis $\mathrm{B}, \mathrm{C}$, or both with hepatocellular carcinoma (HCC). They were numbered and total was 120 patients. By using simple random technique, the cases were selected using table of random number to reach 77 cases. Controls were selected from all cases registered at the place of the study and regularly followed up at the outpatient clinic. Controls were defined as patients with chronic active hepatitis B, C, or both without hepatocellular carcinoma (HCC). They were numbered and total was 400 patients. By using simple random technique, the controls were selected using table of random number to reach 77 controls .

All the following data were collected from all subjects: Personal history, occupational history and medical history of chronic active hepatitis $\mathrm{B}$ and/or $\mathrm{C}$ and HCC. Clinical examination (general and local examination) and investigations included liver function tests, ultrasonography, triphasic CT, alpha feto protein and liver biopsy or fibro scan. Biological monitoring of 1-Hydroxy pyrene in urine was used as a biomarker of exposure to polycyclic aromatic hydrocarbons.

The preparatory phase took about six months from the first of March 2015 till the end of August 2015. During this phase, a review of literature was conducted in order to explain the risk of occupational and environmental exposure to polycyclic aromatic hydrocarbons and biological monitoring of them .

Written permission to implement the study was obtained from Ethic Committee of both Al-Azhar Faculty of Medicine and TBRI. Written permission to implement the study was also obtained from TBRI hospitals authority from the general manager of TBRI and Head of the Department of Hepatology and Gastroentrology at TBRI. Oral approval was taken from every subject before subjecting him to the interview sheet, urine sampling and clinical examination.

Pilot study was conducted to assess patient's impression, reaction and cooperation with the study. The pilot study included 16 patients $(8$ subjects of case group and 8 subjects of control group). No modification of the interview sheet was conducted after the pilot study as respecting culture and time of the examined patients. So, the pilot sample was included in this study.

The implementation phase took about one year, from the first of September 2015 till the end of August 2016. During this phase, the researcher interviewed all included patients separately. Every patient was subjected to the selected parameters, and biological monitoring of urinary 1hydroxy pyrene as a biomarker for PAHs exposure. It took about one and half hour for each subject.

The evaluation phase took about one year from the first of September 2016 till the end of August 2017.

Statistical analysis: The collected data were entered and analyzed using SPSS 
package (version 17.0). Data were presented using frequencies and percentages. The level of 1-hydroxy pyrene in urine was measured and compared between case and control groups by socio-demographic factors using chi square test. $\mathrm{P}$ values $\leq 0.05$ were used as indicators of statistical significance differences between the two studied groups. Odds ratio was also calculated for each studied factor.

\section{RESULTS}

The level of 1-hydroxy pyrene in urine was presented in Table 1. There was statistical significance difference between cases and controls with $\mathrm{p}<.0001(73 \%$ of cases showed abnormal level and about
$50 \%$ of them showed moderate elevation). It was shown that there was a positive association between exposure to PAHs and development of $\mathrm{HCC}(\mathrm{OR}=4.9-$

table 1).

Table (1): 1-Hydroxy pyrene in urine as a biomarker of exposure to Polycyclic Aromatic Hydrocarbons (PAHs) among the studied groups

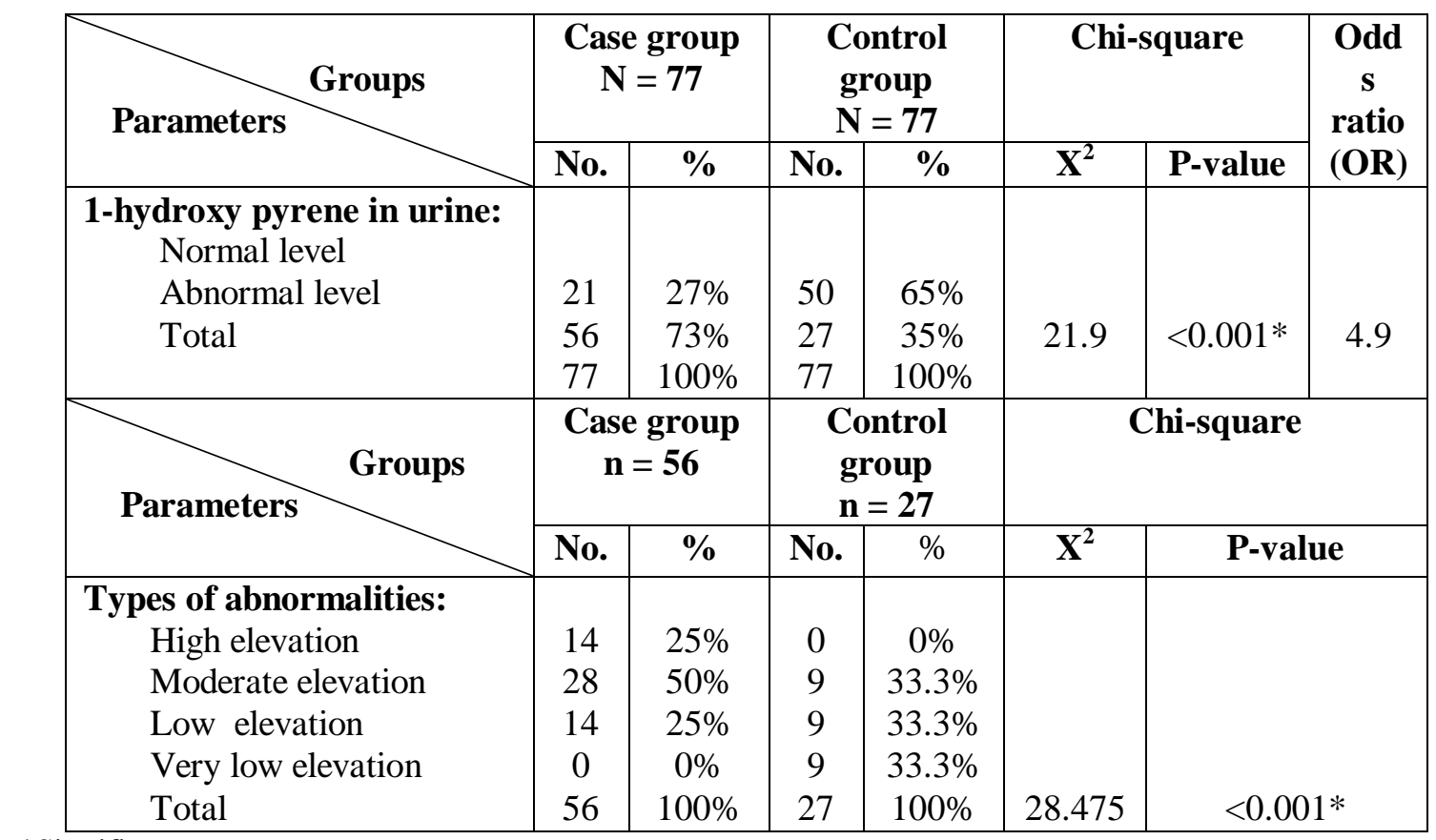

*Significant

The level o 1-hydroxy pyrene in urine in the studied cases and controls by their characteristics was presented in Table 2 . There was $\mathrm{n}$ statistically significant difference between the two groups by their sex, residence, smoking habit, type of hepatitis, $(p>0.05)$. However, it was noticed that males had 1.65 fold more than females to develop HCC on top of chronic active hepatitis $\mathrm{B}$ and $\mathrm{C}$ when exposed to PAHs $(\mathrm{OR}=1.65)$. A positive association between smoking and development of HCC on top of chronic active hepatitis B and $\mathrm{C}$ in case group when exposed to PAHs was also found with odds ratio of 1.7. A very high association, however, between the presence of 1-Hydroxy pyrene in urine and elevated Alfa Feto 
protein (AFP) among the cases $(\mathrm{OR}=$ 316.25), and there was a statistically significant difference between the exposed and non-exposed group $(\mathrm{p}<0.001)$. On the other hand, however, a significant negative association was detected between 1-hydroxy pyrene and signs of decompensation $(\mathrm{OR}=0.10)$ (Table 2).

Table (2): 1-hydroxy pyrene in urine among the studied groups by their characteristics

\begin{tabular}{|c|c|c|c|c|c|c|c|}
\hline \multirow{2}{*}{$\begin{array}{c}\text { Positive 1-hydroxy } \\
\text { pyrene in urine }\end{array}$} & \multicolumn{2}{|c|}{$\begin{array}{c}\text { Case group } \\
\quad \mathrm{N}=56\end{array}$} & \multicolumn{2}{|c|}{$\begin{array}{c}\text { Control group } \\
\mathbf{N}=\mathbf{2 7}\end{array}$} & \multicolumn{2}{|c|}{ Chi square test } & \multirow[t]{2}{*}{$\begin{array}{l}\text { Ratio } \\
\text { (OR) }\end{array}$} \\
\hline & No. & $\%$ & No. & $\%$ & $\mathbf{X}^{2}$ & P-value & \\
\hline $\begin{array}{l}\text { Sex } \\
\text { Male } \\
\text { Females }\end{array}$ & $\begin{array}{l}39 \\
17\end{array}$ & $\begin{array}{l}69.6 \\
30.4\end{array}$ & 16 & $\begin{array}{l}59.3 \\
407\end{array}$ & 08 & 030 & 16 \\
\hline $\begin{array}{l}\text { Residence } \\
\text { Rural } \\
\text { Urban }\end{array}$ & $\begin{array}{l}21 \\
35\end{array}$ & $\begin{array}{l}37.5 \\
62.5\end{array}$ & $\begin{array}{c}9 \\
18\end{array}$ & $\begin{array}{l}33.3 \\
66.7\end{array}$ & 0.1 & 0.70 & 0.8 \\
\hline $\begin{array}{l}\text { Smoking } \\
\text { Smoker } \\
\text { Non smoker }\end{array}$ & $\begin{array}{l}28 \\
28\end{array}$ & $\begin{array}{l}50.0 \\
50.0\end{array}$ & $\begin{array}{l}10 \\
17\end{array}$ & $\begin{array}{l}37 \\
63\end{array}$ & 1.2 & 0.30 & 1.7 \\
\hline $\begin{array}{l}\text { Type of hepatitis } \\
\text { Hepatitis B } \\
\text { Hepatitis C }\end{array}$ & $\begin{array}{l}21 \\
35\end{array}$ & $\begin{array}{l}37.5 \\
62.5\end{array}$ & $\begin{array}{c}7 \\
20\end{array}$ & $\begin{array}{l}26.0 \\
74.0\end{array}$ & 0.1 & 0.30 & 0.6 \\
\hline $\begin{array}{l}\text { Alfa Feto Protein (AFP) } \\
\text { Normal } \\
\text { Elevated }\end{array}$ & $\begin{array}{c}1 \\
55\end{array}$ & $\begin{array}{c}1.8 \\
98.2\end{array}$ & $\begin{array}{c}23 \\
4\end{array}$ & $\begin{array}{l}85.2 \\
14.8\end{array}$ & 61.6 & $<0.001 *$ & 316.25 \\
\hline $\begin{array}{l}\text { Signs of decompensation } \\
\text { Present } \\
\text { Absent }\end{array}$ & $\begin{array}{l}35 \\
21\end{array}$ & $\begin{array}{l}62.5 \\
37.5\end{array}$ & $\begin{array}{c}25 \\
2\end{array}$ & $\begin{array}{l}92.6 \\
7.4\end{array}$ & 8.2 & $0.004 *$ & 0.10 \\
\hline
\end{tabular}

*Significant

\section{DISCUSSION}

Regarding biological monitoring of 1Hydroxy pyrene in urine as a biomarker of exposure to Polycyclic Aromatic Hydrocarbons (PAHs) among the studied groups (Table 1), there was significant association between exposure to $\mathrm{PAHs}$ and development of HCC $(\mathrm{OR}=4.9)$. This agreed with Lee et al. (2009), Shahataheri (2009), Van Larebeke et al. (2010), and Hansen et al. (2013). They reported the exposure to PAHs might be a risk factor of lung, kidney, renal and testicular cancer. Also, agreed with Jing
Yang et al. (2017) who concluded that the data of their study reinforce that urinary 1hydroxy pyrene can be a useful biomarker for evaluating total PAHs exposure and in assessing the effect of PAHs exposure on oxidative damage. This agreed with Guohang et al. (2012) who concluded that PAHs are found in the human rectal tissues or hepatic tissues. The content of PAHs in the human rectal tissues may have affection on the occurrence of rectal cancer while the content of PAHs in the hepatic tissues may have ones . 
Concerning the relation of 1-Hydroxy pyrene in urine and the characteristics of the studied groups, there was significant statistical association between the presence of 1-Hydroxy pyrene in urine and sex of examined subjects and males had 1.65 fold more than females to develop HCC on top of chronic active hepatitis $\mathrm{B}$ and $\mathrm{C}$ when exposed to PAHs $(\mathrm{OR}=1.6)$. This agreed with Dong and Lee (2009) who reported that positive association between male and exposure to PAHs for development of cancer. But this disagreed with Oanh et al. (2009) who found no association between sex and exposure to PAHs for development of cancer. The discrepancies in the result of that study and other ones might be attributed to the type of study population. In the present study, the target population was those of hepatitis with the cases were those with HCC. Also, the rate may varies in the discrepant studies. In some studies, it was found that higher concentrations of exposure to PAHs were among females than compared with males, likely due to more exposure from the cooking stoves and wood combusted heating in certain communities (Zhang et al., 2014).

In the view of the relation of 1Hydroxy pyrene in urine and the residence of the examined groups (Table 2), it was found no statistically significant difference between the two groups, and no association between exposure to PAHs in urban areas and development of HCC on top of chronic active hepatitis $\mathrm{B}$ and $\mathrm{C}$ in the case group $(\mathrm{OR}=0.8)$. This disagreed with the results of Dong and Lee (2009) who stated that increase the risk of cancer due to exposure to PAHs in the urban areas and explained that by more exposure to industrial and mobile sources.
As regards the relation of 1-Hydroxy pyrene in urine and smoking habit among the examined groups. Although no statistically significant difference between the two groups, there was positive association between smoking and development of HCC on top of chronic active hepatitis $\mathrm{B}$ and $\mathrm{C}$ in the case group when exposed to PAHs $(\mathrm{OR}=1.7)$. This agreed with Yang et al. (2009), Li \& Ro (2010), and Poppi and Silva (2015) who reported that positive association between smoking and development of HCC among cases of chronic active hepatitis B or C. This agrees also with (Jing Yang et al., 2017) who found that smoking can significantly increase the level of 1hydroxy pyrene in urine in cases exposed to PAHs and smoking will cause more serious DNA oxidative damage among the exposed cases to PAHs and agreed with Zhu et al. (2011) who concluded that the major route of exposure to PAHs in the general population is from breathing ambient air polluted with PAHs and indoor eating food containing PAHs, cigarettes smoking or breathing smoke from open fire.

Regarding the relation of 1-Hydroxy pyrene in urine and different types of hepatitis among the examined groups, there was neither statistical significance difference between the two groups nor association between cases of chronic active hepatitis $\mathrm{C}$ and development of HCC when exposed to PAHs. This might be explained by effect of hydrocarbons in development of hepatic cancer not determined with type of viral hepatitis.

As regards the relation of 1-Hydroxy pyrene in urine and AFP among the examined groups, there was a highly 
positive association between abnormal level of 1-Hydroxy pyrene in urine and elevated AFP and there was a statistical significance difference between exposed and non-exposed groups. This could be attributed to exposure to PAHs has a positive effect on the level of AFP. Chronic exposure AFP is a major risk factor for HCC; increased risk has been linked to polycyclic aromatic hydrocarbon (PAH) co-exposure and hepatitis virus infection (Johnson et al., 2010). Furthermore, since hepatitis viruses are major etiological factors for liver cancer (McGlynn et al., 2015 and MakarovaRusher et al., 2016) and HBV infection interacts with AFP exposure to greatly increase liver cancer risk (Smith et al., 2017), hepatitis virus exposures should be assessed in conjunction with AFP.

Concerning the relation of 1-Hydroxy pyrene in urine and signs of decompensation among the examined groups, there was negative association between the two abnormalities. Although no similar studies in the literature have found to address this point, the explanation of this finding might be attributed to liver state of cirrhosis and cancer not the exposure to PAHs. PAH metabolism usually occurring in the liver like most xenobiotics and hydrocarbons. The enzyme system that is primarily responsible for $\mathrm{PAH}$ metabolism is the mixed-function oxidase system (Hodgson and Rose, 2010 and Wohak et al., 2016). The progress of liver fibrosis and cirrhosis is accompanied by deteriorating liver function, including functional changes in phase I and phase II metabolic enzymes (Dietrich et al. 2016).

\section{CONCLUSION}

Cases of HCC had increased level of 1hydroxy pyrene in urine with statistical significance difference when compared to controls. There was a significant positive association between exposure to PAHs and development of HCC among males and smokers. There was neither statistical significance difference nor positive association between exposure to PAHs and development of HCC in urban areas and among patients with chronic active hepatitis. There was a highly positive correlation between 1-hydroxy pyrene and Alfa Feto Protein (AFP) among positive cases of 1-hydroxy pyrene in case group.

\section{RECOMMENDATIONS}

Elimination of exposure to PAHs is needed. Environmental monitoring of PAHs in different residential areas in different governorates for detection of source of pollution with PAHs in air, soil and water is needed.

\section{REFERENCES}

1. Angerer J and Schaller K H. (2009): 1Hydroxypyrene. In Analyses of Hazardous Substances in Biological Materials, Volume 3, Angerer $\mathrm{J}$ and Schaller $\mathrm{KH}$ (eds), Weinheim, Germany, pp. 151-170.

2. Dietrich CG, G?tze $O$ and Geier A. (2016): Molecular changes in hepatic metabolism and transport in cirrhosis and their functional importance. World J Gastroenterol., 22(1):7288.

3. Dong TTT and Lee BK. (2009): Characteristics, toxicity, and source apportionment of polycyclic aromatic hydrocarbons (PAHs) in road dust of Ulsan, Korea. Chemosphere, 74:1245-1253.

4. Egyptian Environmental Affairs Agency (EEAA) (2011): Egyptian environmental quality report, 2011, Cairo, Egypt. 
5. El-Zayadi A, Rahman H, Abaza S, Shawky M.K, Mohamed OE and Selim HM. (2011): Prevalence and epidemiological features of hepa- tocellular carcinoma in Egypt-a single center experience. Hepatol. Res., 19:170-179.

6. Ezzat SM, Abdel-Hamid SA, Eissa N, Mokhtar NA, Labib L and El- Ghorory NN. (2014): Associations of pesticides, $\mathrm{HCV}, \mathrm{HBV}$, and hepatocel-lular carcinoma in Egypt. Int. J. Hyg. Environ. Health, 208 (5): 329-339.

7. Guohang J, Limin L and Liyuan C. (2012): Quantitative measurement of polycyclic Aromatic Hydrocarbon (PAH) and its metabolites in different body tissues. The Chinese-German Journal of Clinical Oncology, 11(7): 391-394.

8. Hassan M, Zaghloul AS, El-Serag HB, Soliman O, Patt YZ and Chappell CL. (2011): The role of hepatitis $C$ in hepatocellular carcinoma: a case control study among Egyptian patients, J. Clin. Gastroenterol., 33 (2):123-126.

9. Hansen AM, Mathiesen L, Pedersen M and Knudsen LE. (2013): Urinary 1hydroxypyrene (1-HP) in environmental and occupational studies-A review. Int $\mathrm{J}$ Hyg Environ Health. ,211(5-6):471-503.

10. Hodgson $\mathbf{E}$ and Rose L. (2010): metabolism of toxicants. In Hodgson E (ed) A textbook of modern toxicology, 4th edition. Wiley, Hoboken NJ, USA, pp115-156.

11. Johnson NM, Qian $G$ and $X u$ L. (2010): Aflatoxin and PAH exposure biomarkers in a U.S. population with a high incidence of hepatocellular carcinoma. Sci Total Environ., 408(23):6027-6031.

12. Lee MS, Eum KD, Lee K, Kim $H$ and Paek L. (2009): Seasonal and regional contribu-tors of 1-hydroxypyrene among children near a steel mill. Cancer Epidemiol Biomarkers Prev., 18(1):96-101.

13. Li CS and Ro YS. (2010): Indoor characteristics of polycyclic aromatic hydrocarbons in the urban atmosphere of Taipei. Atmospheric Environment, 34:611620.
14. Makarova-Rusher $O \mathrm{~V}$, Altekruse SF, McNeel TS, Ulahannan S, Duffy AG, and Graubard BI. (2016): Population attributable fractions of risk factors for hepatocellular carcinoma in the United States. Cancer, 122: 1757-1765.

15. McGlynn KA, Petrick JL and London WT. (2015): Global Epidemiology of Hepatocellular Carcinoma: An Emphasis on Demographic and Regional Variability. Clin Liver Dis., 19: 223-238.

16. Oanh NTK, Reutergardh LB and Dung NT. (2009): Emission of polycyclic aromatic hydrocarbons and particulate matter from domestic combustion of selected fuels. Environmental Science and Technology, 33:2703-2709.

17. Poppi NR and Silva MS. (2015): Polycyclic aromatic hydrocarbons and other selected organic compounds in ambient air of Campo Grande City, Brazil. Atmospheric Environment, 39:2839-2850.

18. Shahtaheri SJ. (2009): Solid phase extraction for 1-hydroxypyrene as a bio $\neg$ marker of occupational exposure to PAHs prior to high performance liquid chromatography. Iran J Chem Chem Eng., 26(4):75-81.

19. Smith JW, Kroker-Lobos MF and Lazo M. (2017): Aflatoxin and viral hepatitis exposures in Guatemala: Molecular biomarkers reveal a unique profile of risk factors in a region of high liver cancer incidence. PLoS One., 12(12):e0189255

20. Van Larebeke NA, Bracke ME, and Nelen VV. (2010): Differences in tumor-associated protein levels among middle-age Flemish women in association with area of residence and exposure to pollutants. Environ Health Perspect., 114:887-92.

21. Wohak LE, Krais AM and Kucab JE. (2016): Carcinogenic polycyclic aromatic hydrocarbons induce CYP1A1 in human cells via a p53-dependent mechanism. Arch Toxicol., 90(2):291-304.

22. World Health Organization (WHO) (2013): Guidelines for drinking-water quality, background document on plynuclear 
aromatic hydrocarbons in drinking-water. WHO, Geneva, 2013.

23. Yang HH, Jung RC, Wang YF and Hsieh LT. (2009): Polycyclic aromatic hydrocarbon emissions from joss paper furnaces. Atmospheric Environment, 39: 3305-3312.

24. Yang J, Zhang H, Zhang H, Wang W, Liu Y and Fan Y. (2017): Int Arch Occup Environ Health, 90:423-431.

25. Zhang Y, Ding J and Shen G. (2014): Dietary and inhalation exposure to polycyclic aromatic hydrocarbons and urinary excretion of monohydroxy metabolites - a controlled case study in Beijing, China. Environ Pollut. 2014,184:515-522.

26. Zhu X, Fan ZT and Wu X. (2011): Ambient concentrations and personal exposure to polycyclic aromatic hydrocarbons (PAH) in an urban community with mixed sources of air pollution. J Expo Sci Environ Epidemiol., 21(5):437-449. 


\title{
المراقبة البيولوجية للهيدروكربونات العطرية متعددة الحلقات كعامل

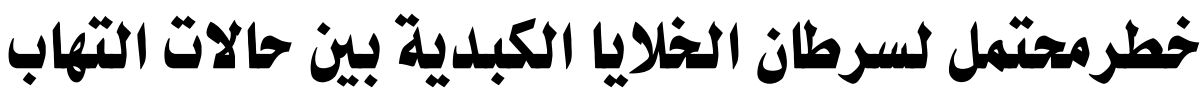

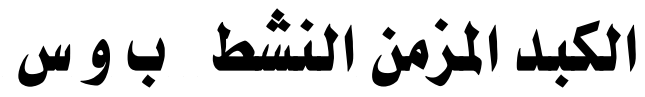

رائد محمد عزب*,علاء عبدالواحد*, إلهام علي مطاوع* , شريف أحمد مرسي****

\author{
*أحمد سيا عبدربها', \\ قسم طب المجتمع و طب الصناعات كلية ـ طب الازهر * \\ قسم الباثوليجييا الإكلينيكية ـ كلية طب الازهر ** \\ معهز تيودور بلهارس للابحاث***
}

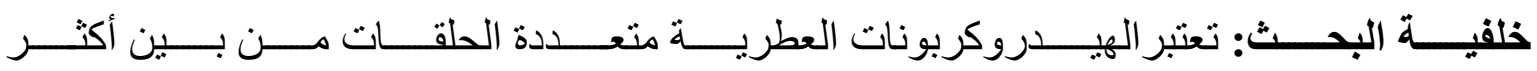

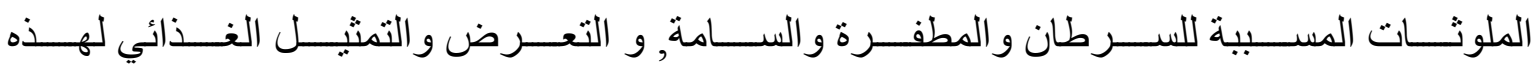

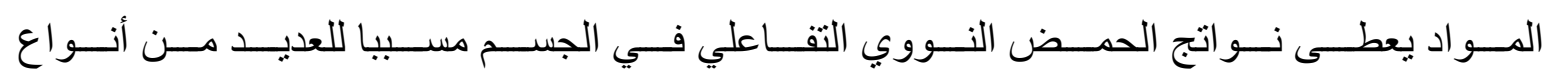
السرطان البشري.

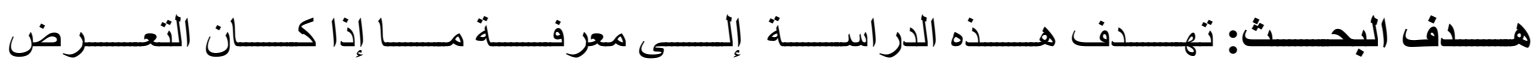

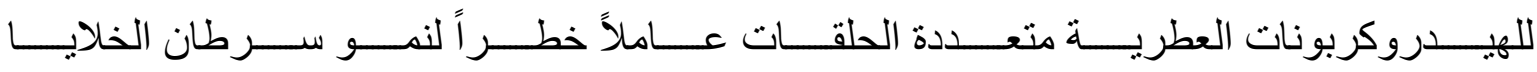

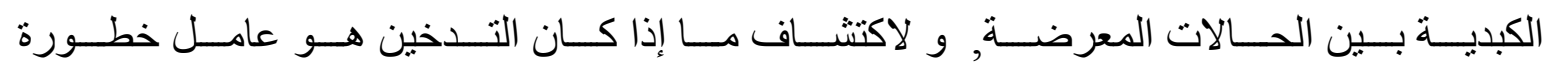

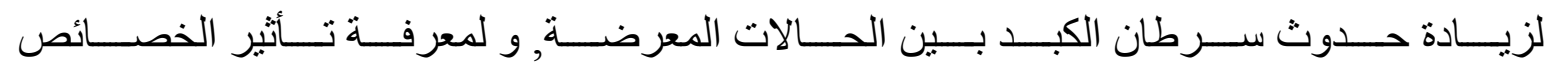

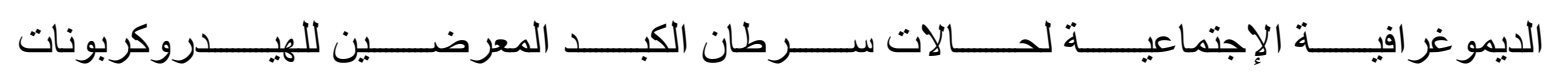
العطرية متعددة.

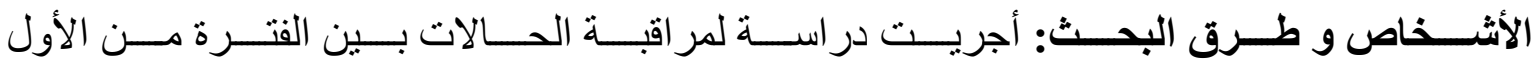

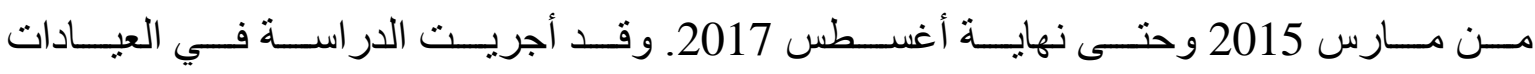

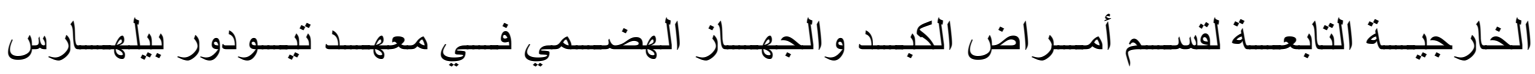

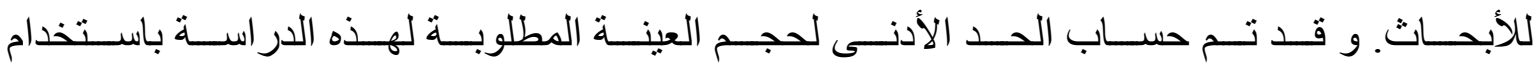

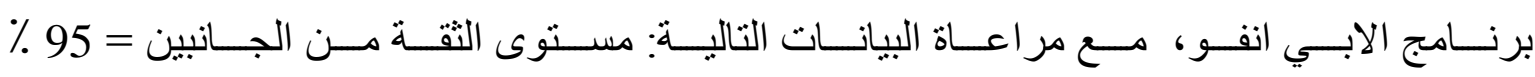

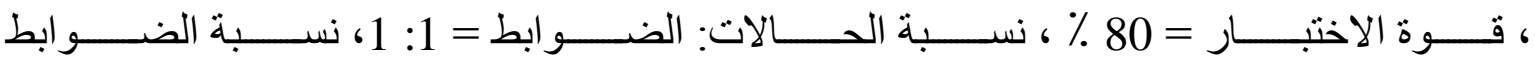

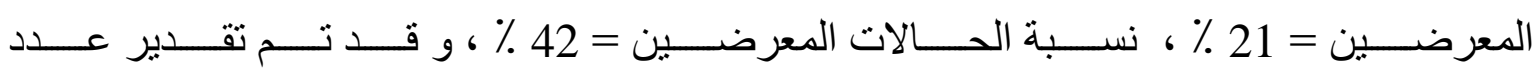




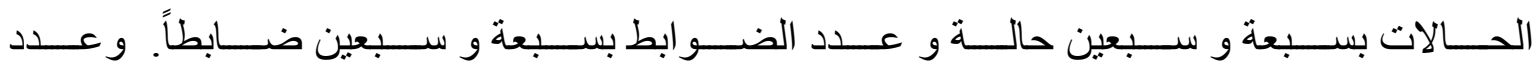

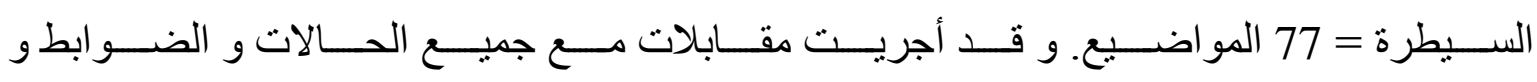

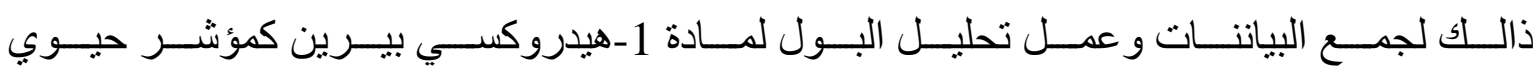
للتعرض الهيدروكربونات العطرية متعددة الحلقات.

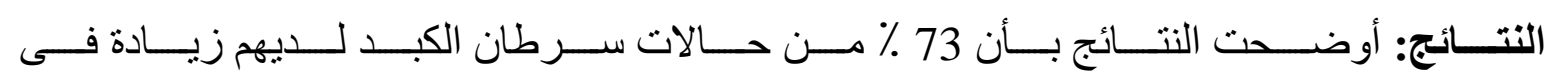

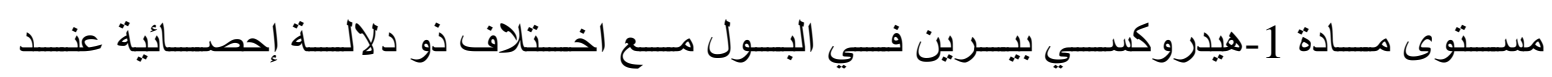

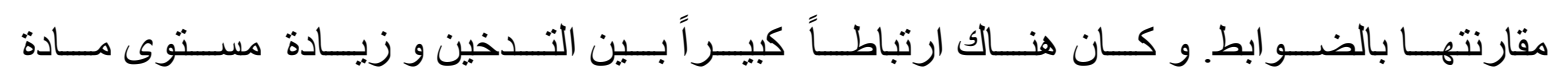

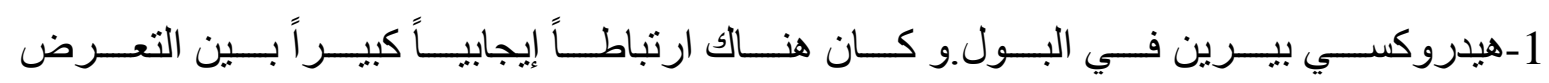

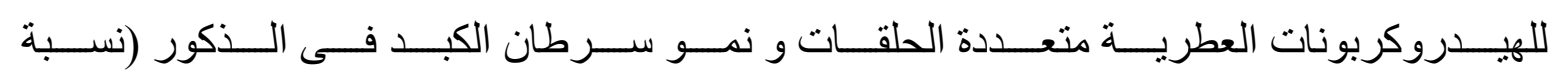

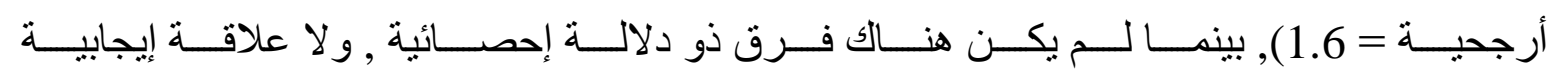

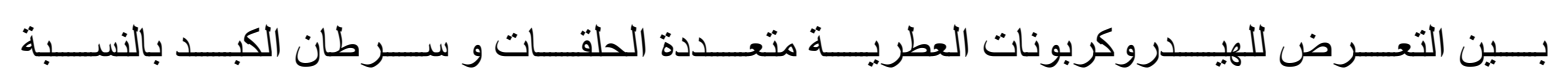

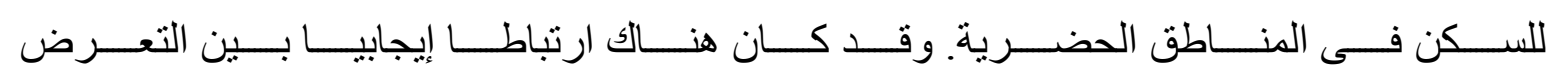

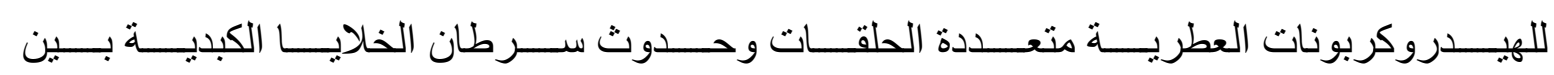

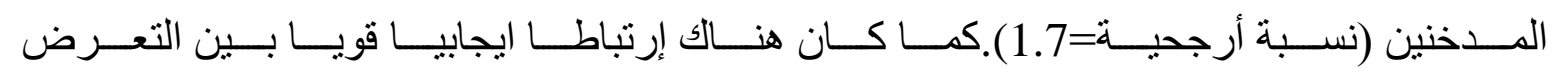

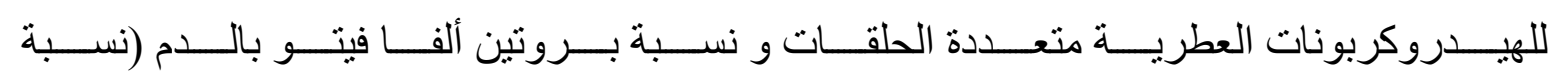
أرجحية=0. (316.25).

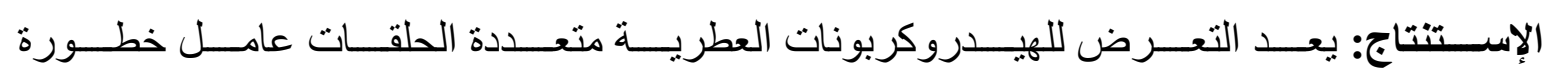

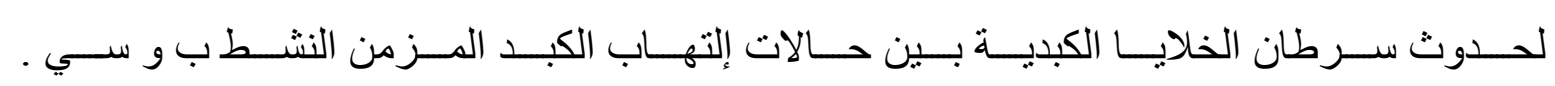

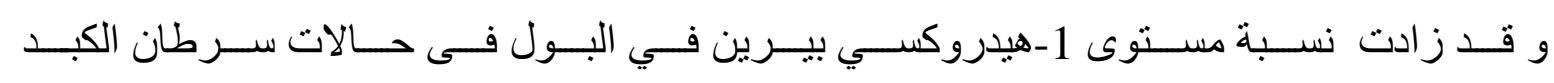

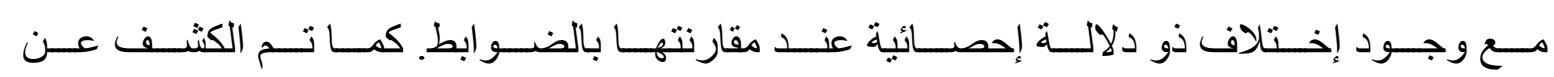

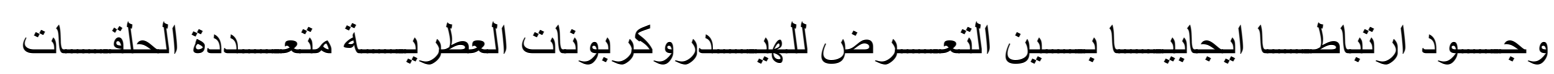
وسرطان الكبد فى الذكور و المدخنين. 